\title{
PENGEMBANGAN MODEL MATERI AJAR SEMANTIK: Penelitian dan Pengembangan Model Materi Ajar Semantik di Program Studi Bahasa, Sastra Indonesia, dan Daerah FKIP Universitas Jambi
}

\author{
Ade Kusmana \\ Pendidikan Bahasa dan Seni (PBS) FKIP Universitas Jambi \\ Jl. Jambi Muara Bulian Mendalo Darat Jambi \\ Email: dr.akusmana@gmail.com
}

\begin{abstract}
Abstrak:
Tujuan penelitian ini adalah untuk menghasilkan produk model materi ajar semantik sebagai mata kuliah di Program Studi Pendidikan Bahasa, Sastra Indonesia, dan FKIP Universitas Jambi. Pendekatan penelitian ini adalah pengembangan $\mathrm{R}$ and $\mathrm{D}$ (Research and Development). Urgensi penelitian ini, pembelajar kurang menguasai materi ajar semantik yang telah di ajarkan ditandai dengan rendah nilai yang diperoleh. Kekurangmampuan ini, mengakibatkan tidak tercapainya visi, misi, dan tujuan yang telah ditetapkan, tidak terpenuhi. Dengan demikian sangat perlu dilakukan penelitian dan perlu pengembangan materi ajar semantik. Hasil penelitian diperoleh gambaran berupa (1) model teoretik, (2) gambaran tentang kebutuhan mahasiswa dan dosen pengfajar terhadap materi ajar diperoleh melalui (a) hasil analisis kurikulum, (b) hasil analisis silabus, dan (c) hasil analisis materi ajar semantik bahasa Indonesia, (3) gambaran silabus dan materi ajar semantik bahasa Indonesia yang telah dikembangkan layak digunakan di Program Studi Pendidikan Bahasa Indonesia, sastra Indonesia, dan Fakultas Keguruan dan Ilmu Pendidikan Universitas Jambi.
\end{abstract}

\begin{abstract}
:
The purpose of this research was to create a semantik teaching material product as the a course for the Program of Language Education, Indonesian literure, and FKIP Jambi University. The research approach used was research and development. The urgency of this research was the fact that students did not master the semantic teaching material that had been thought and the low mark obtained by the them. This low ability resulted in not achieving the vision, mission, and the goal that have been stated. Therefore, it is very important to conduct a research and develop semantic teaching material. The result of the research show the description of (1) theoretical mode;(2) the need of the students and lecturer to the teaching material obtained from the result of (a) cirriculum anlysis, (b)syllabus analysis, and (c) Indonesian semantic teaching material; (3) the description of syllabus and Indonesia semantic teaching material that has been developed and proved to be appropriate to be used in the Program of Language Education, Sastra Indonesia, and FKIP Jambi University.
\end{abstract}

Kata kunci:

Pengembangan, model materi ajar, semantik bahasa Indonesia

TUJUAN Program Studi Pendidikan Bahasa, Sastra Indonesia dan Daerah adalah: (a) menghasilkan lulusan yang berkualitas dan berdaya saing di bidang Bahasa, Sastra Indonesia dan Daerah; (b) minat, bakat, apresiasi, dan kreativitas mahasiswa di bi- 
dang Bahasa, Sastra Indonesia dan Daerah yang tumbuh dan berkembang; (c) iklim yang kondusif bagi dosen untuk melaksanakan Tridarma Perguruan Tinggi; dan (d) tenaga dosen berdaya menurut keahliannya dalam membina dan mengembangkan Bahasa, Sastra Indonesia dan Daerah.

Kurikulum semantik Bahasa Indonesia yang digunakan di Program Studi Pendidikan Bahasa, Sastra Indonesia dan Daerah sebagai berikut: (a) pembahasan makna dalam Bahasa Indonesia yang mencakup: makna leksikal dan gramatikal, denotatif dan konotatif, lugas dan kias, serta makna dasar dan ubahan; (b) pembahasan kerelasian makna dalam Bahasa Indonesia mencakup: sinonimi dan antonimi, relasi polisemi dan homonimi; (c) pembahasan pengertian perubahan makna, sebab-sebab perubahan makna, dan arah perubahan; (d) pembahasan pengertian ungkapan tabu, jenis-jenisnya, dan strategi penghindarannya.

Kedudukan mata kuliah semantik pada Program Studi Pendidikan Bahasa, Sastra, dan Sastra Daerah sebagai mata kuliah prasarat yang wajib diambil, diajarkan pada semester empat dengan bobot 2 (dua) sks.

Tujuan mata kuliah semantik, Mahasiswa mampu memahami Semantik yang digunakan dalam kehidupan sehari-hari, baik secara lisan maupun tulisan. Oleh karena itu tujuan yang diharapkan dengan sajian mata kuliah pada perkuliahan tersebut adalah agar mahasiswa mampu memahami semantik.

Untuk memenuhi hal tersebut, pada penelitian dilakukan dengan tujuan mendisain pengembangan materi ajar yang memenuhi tuntutan itu. Oleh karenanya sangat perlu dikembangkan suatu model materi ajar yang refresentatif untuk dijadikan pegangan bagi pengajar dan pemelajar selain kurikulum di Program Studi Pendidikan Bahasa, Sastra Indonesia dan Daerah.

Nasution mengemukakan bahwa buku pelajaran (materi ajar) merupakan salah satu alat teknologi pendidikan yang memberi keuntungan antara lain: (1) membantu pengajar melaksanakan kurikulum, (2) pegangan dalam menentukan metode pengajaran, (3) memberi kesempatan kepada peserta didik untuk mengulangi pelajaran atau mempelajari pelajaran baru, (4) memberikan kontinuitas pelajaran di kelas yang berurutan sekalipun pengajar berganti. ${ }^{1}$ Begitu pula Tarigan mengemukakan bahwa buku materi ajar adalah sarana belajar yang bisa digunakan di sekolah-sekolah dan di Perguruan tinggi untuk menunjang suatu program pengajaran. ${ }^{2}$

Dengan pengembangan materi ajar secara sistemik dan berkesinambungan akan dapat menghasilkan buku materi ajar semantik yang sangat dibutuhkan khususnya oleh pengajar dan pemelajar di Program Studi Pendidikan Bahasa, Sastra Indonesia dan Daerah sehingga kesulitan-kesulitan yang dialami pengajar dan pemelajar dalam mempelajari dan memahami materi ajar semantik dapat diatasi dengan baik dengan memiliki buku materi ajar semantik, di samping motivasi belajar. Materi ajar yang memenuhi tuntutan visi, misi dan tujuan tersebut, tentu harus memenuhi tuntutan kebutuhan pengajar dan pemelajar yang diharapkan sebagaimana yang telah dijelaskan terdahulu. 


\section{Tujuan Penelitian}

Tujuan penelitian yang hendak dicapai adalah mendapatkan model materi ajar semantik yang memenuhi kebutuhan pengajar dan pemelajar yang dapat digunakan di Program Studi Bahasa, Sastra Indonesia dan Daerah FKIP Universitas Jambi.

\section{KAJIAN TEORI}

\section{Teori Semantik}

Objek kajian semantik yakni makna, berada di seluruh atau di semua tataran yang bangun-membangun ini. Makna berada di dalam tataran fonologi, morfologi, dan sintaksis. Penamaan tataran untuk semantik agak kurang tepat, sebab dia bukan satu tataran dalam arti unsur membangun satuan lain yang lebih besar, melainkan merupakan unsur yang berada pada semua tataran itu, meskipun kehadirannya pada tiap tataran itu tidak sama. Para linguis strukturalis tidak begitu peduli dengan masalah makna ini, karena dianggap tidak termasuk atau menjadi tataran yang sederajat dengan tataran yang bangun-membangun itu. Hockett, salah seorang tokoh strukturalis menyatakan bahwa bahasa adalah suatu sistem yang kompleks dari kebiasaankebiasaan. ${ }^{3}$ Sistem bahasa terdiri atas lima subsistem, yaitu: subsistem gramatika, subsistem fonologi, subsistem morfofonemik, subsistem semantik, dan subsistem fonetik.

\section{Makna}

Leech menyatakan bahwa pembahasan pengertian makna (meanings of meaning) sebagai awal studi yang penting pada semantik dan banyak dipermasalahkan mengenai kata 'meaning' di dalam bahasa Inggris dan para ahli semantik. ${ }^{4}$ Lyons menyebutkan bahwa memberikan makna suatu kata ialah dengan memahami kajian kata berbeda dengan kata-kata lain. Arti dalam hal ini menyangkut makna leksikal dari katakata itu sendiri, yang cenderung terdapat di dalam kamus, sebagai leksem. ${ }^{5}$

Sebuah kata yang digunakan dalam konteks kalimat akan menngandung makna yang berbeda juga mempunyai makna yang tidak sama. Misal makna kata mengambil pada kalimat-kalimat berikut:

1. Semester ini saya belum mengambil mata kuliah sintaksis.

2. Tahun ini kami akan mengambil sepuluh orang pegawai baru.

3. Dia bermaksud mengambil gadis itu menjadi istrinya.

4. Sedikitpun saya tidak mengambil untung.

5. Kita bisa mengambil hikmah dari kejadian itu.

6. Saya akan mengambil gambar peristiwa bersejarah itu.

7. Diam-diam dia mengambil buku itu dari tasmu.

Kita tentu memahami bahwa kata mengambil pada ketujuh kalimat itu memiliki makna yang tidak sama. Pada kalimat (1) kata mengambil bermakna 'mengikuti', pada kalimat (2) bermakna "menerima", pada kalimat (3) bermakna "menjadikan", pada kalimat (4) bermakna "memperoleh", pada kalimat (5) "memanfaatkan", pada kalimat (6) bermakna "membuat/memotret", dan pada kalimat (7) bermakna "mencuri". 


\section{Jenis Makna}

Berbagai nama jenis makna telah dikemukakan oleh para pakar bahasa dalam berbagai buku linguistik atau semantik. Kiranya jenis-jenis makna yang dibicarakan pada pembahasan berikut ini dapat mewakili jenis-jenis makna yang pernah dibicarakan para pakar yaitu: makna lesikal, gramatikal, kontekstual; makna referensial dan non-referensial serta deiktik; makna denotatif, makna konseptual, dan makna asosiasi; makna kata dan makna istilah; dan makna idiom dan pribahasa.

\section{Relasi Makna}

Relasi makna yang dimaksud adalah relasi makna atau hubungan semantik antarsatuan bahasa. Satuan bahasa yang terlibat bisa level kata, frase, klausa, dan kalimat. ${ }^{6}$ Berdasarkan pernyataan tersebut bahwa yang dimaksud relasi makna adalah hubungan semantik yang terdapat antara satuan bahasa yang satu dengan satuan bahasa lainnya. Satuan bahasa dapat berupa kata, frase, maupun kalimat; dan relasi semantik. Berdasarkan sifat relasinya, relasi makna meliputi: menyatakan kesamaan makna (sinonim), pertentangan makna (antonim), ketercakupan makna (polisemi), kegandaan makna (ambigu/ketaksaan) atau kelebihan makna (homonim), majas metafor.

\section{Perubahan Makna}

Tarigan menyakan bahwa terjadinya perubahan semantik atau makna sering bersamaan dengan perubahan sosial yang disebabkan oleh peperangan, perpindahan penduduk, kemajuan teknologi dan ilmu pengetahuan, ekonomi, budaya, dan faktorfaktor lainnya. ${ }^{7}$

Ullmann menjelaskan bahwa faktor-faktor perubahan makna adalah (1) bahasa diwariskan dari generasi ke generasi, dimana setiap anak harus mempelajarinya dan sudah menjadi pengetahuan umum bahwa anak-anak akan selalu salah memahai makna kata-kata. (2) kesamaran dalam makna, berhubungan dengan makna, berhubungan dengan sifat generik kata-kata kurangnya pengetahuan ketiadaan batas-batas merupakan penyebab perubahan makna. (3) hilangnya motivasi. (4) eksistensi dari polisemi. (5) muncul dalam konteks abiguitas dimana kata tertentu memiliki makna yang berbeda, (6) Struktur kosa kata, terdiri dari sejumlah unit-unit terbesar jauh lebih leluasa dan unsur-unsur baru kata-kata maupun makna dapat ditambahkan lebih bebas, sementara unsur-unsur yang sudah ada mudah untuk dihilangkan. ${ }^{8}$

Berdasarkan pernyataan di atas bahwa terjadinya perubahan makna seiring dengan perubahan sosial. Dalam masa yang relatif singkat makna sebuah kata akan tetap sama, tidak berubah, tetapi dalam waktu yang relatif lama ada kemungkinan makna sebuah kata akan berubah.

1. Pertama, perkembangan atau kemajuan dalam bidang ilmu dan teknologi. Umpama, kata sastra pada mulanya bermakna 'tulisan, huruf, lalu berubah menjadi 'ba- 
caan'; kemudian berubah lagi menjadi bermakna 'buku yang baik isinya dan baik pula bahasanya'.

2. Kedua, perkembangan sosial budaya. Kata saudara, misalnya, pada mulanya 'seperut' atau 'orang yang lahir dari kandungan yang sama', tapi kini kata saudara digunakan juga untuk menyebut orang lain sebagai kata sapaan sederajat.

3. Ketiga, perkembangan pemakaian kata. Misal, kata menggarap dari bidang pertanian digunakan juga dalam bidang lain dengan makna, 'mengerjakan, membuat'.

4. Keempat, pertukaran tanggapan indaria. Misal, rasa pedas yang seharusnya ditangkap oleh alat indra perasa lidah menjadi ditangkap oleh alat pendengar telinga, seperti dalam ujaran 'kata-katanya sangat pedas'.

5. Kelima, adanya asosiasi. Misal, kata amplop sebenarnya adalah 'sampul surat', tetapi amplop juga bermakna 'uang sogok'.

\section{Medan Makna dan Komponen Makna}

Kata-kata yang berada dalam satu kelompok lazim dinamai kata yang berada dalam satu medan makna atau satu makna leksikal. Sedangkan usaha untuk menganalisis kata atau leksem atas unsur-unsur makna yang dimilikinya disebut analisis komponen makna atau analisis ciri-ciri makna, atau juga analisis ciri-ciri leksikal.

\section{Pengajaran Semantik}

Pengajaran semantik merupakan salah satu mata kuliah yang wajib diambil di Program Studi Pendidikan Bahasa, Sastra Indonesia dan Daerah. Mata kuliah ini ditawarkan pada semester IV dengan bobot 2 dua SKS. Tujuan mata kuliah semantik agar pemelajar mampu memahami materi ajar semantik yang ada hubungannya dengan kehidupan sehari-hari, baik secara lisan maupun tulisan. Oleh karena itu tujuan yang diharapkan dengan sajian mata kuliah pada perkuliahan tersebut adalah agar maha pemelajar mampu memahami materi ajar semantik.

Semantik termasuk ilmu bahasa. Ilmu bahasa terdiri atas empat tataran, yaitu fonologi, morfologi, sintaksis, dan semantik. Dari keempat cabang ilmu tersebut dapat dibagi menjadi dua bagian besar,yaitu tata bahasa (gramatika) atau struktur bahasa dan di luar gramatika atau di luar struktur bahasa.

Pengajaran semantik Bahasa Indonesia adalah salah satu mata kuliah yang harus mahapemelajar pelajari dalam kelompok mata kuliah kebahasaan. Mata kuliah ini mencakup pembahasan tentang teori semantik secara umum dan sistem makna bahasa Indonesia. ${ }^{9}$ Pengajaran semantik yang harus dipelajari adalah:

1. Makna dalam Bahasa Indonesia yang mencakup: makna leksikal dan gramatikal, denotatif dan konotatif, lugas dan kias, dan makna dasar dan ubahan,

2. Kerelasian makna yang mencakup: sinonim, antonim, polisemi, hiponimi, dan homonimi,

3. Pengertian perubahan makna, sebab-sebab perubahan makna, dan arah perubahan,

4. Pengertian ungkapan tabu, jenis-jenisnya, dan strategi penghidarannya. 


\section{METODE PENELITIAN}

\section{Tempat dan Waktu Penelitian}

Penelitian ini dilaksanakan di Program studi Bahasa, Satra Indonesia, dan Satra Daerah FKIP Universitas Jambi. Penelitian dilakukan untuk memenuhi kebutuhan pemelajar dan pengajar, juga untuk meningkatkan kualitas materi ajar semantik Bahasa Indonesia. Penelitian dilaksanakan mulai bulan Pebruari sampai dengan Mei 2011.

\section{Metode Penelitian}

Dalam penelitian ini mempunyai tujuan yakni dihasilkannya suatu produk model materi ajar semantik. Untuk memenuhi tujuan penelitian tersebut penelitian ini perlu mendisain dengan model pendekatan penelitian dan pengembangan $\mathrm{R}$ and $\mathrm{D}$ (research and development). Penelitian pengembangan materi ajar semantik adalah penelitian yang dapat menghasilkan produk, sehingga metode yang digunakan dalam penelitian ini adalah metode penelitian dan pengembangan menurut Borg dan Gall.

Menurut Borg dan Gall penelitian dan pengembangan adalah suatu proses yang digunakan untuk mengembangkan dan memvalidasi produk-produk pendidikan seperti silabus, materi ajar, buku teks, metode pembelajaran, dan lain sebagainya yang dilakukan dalam suatu siklus penelitian dan pengembangan. ${ }^{10}$

Rancangan dan pengembangan sebagai suatu ilmu harus terikat dengan pengertian atau pemahaman yang dibangun atas penelitian empiris yang replikatif. Model dan prosedurnya harus divalidasi dan solusi permasalahan harus didukung oleh data. Menurut Richey dan Klein basis pengetahuan rancangan dan pengembangan memiliki enam komponen utama, yaitu:

1. Para pemelajar bagaimana mereka belajar;

2. Konteks di mana pembelajaran dan performa berlangsung;

3. Sifat dari isi dan bagaimana urutannya;

4. Strategi pengajaran dan kegiatan yang dilaksanakan;

5. Media dan sistem penyajian;

6. Para perancang sendiri dan proses yang mereka gunakan. ${ }^{11}$

\section{Sasaran Penelitian atau Target Penelitian}

Sasaran penelitian dalam penelitian ini adalah pengguna dari pengembangan model materi ajar ini, yakni pengajar (dosen) dan pemelajar (mahasiswa) yang mengontrak mata kuliah semantik yang diselenggarakan pada semester IV (empat) di Program studi Pendidikan Bahasa, Satra Indonesia, dan Daerah FKIP Universitas Jambi.

\section{Langkah-langkah Penelitian dan Pengembangan}

Semiawan mengemukakan bahwa siklus dasar R \& D selalu mencakup siklus kajian - evaluasi - pengembangan. Sementara itu prosedur R \& D langkah-langkahnya yaitu sepuluh langkah Penggunaan Metode Research \& Development (R \&D) yaitu: (1) Potensi Masalah, (2) Mengumpulkan Data, (3) Desain Produk, (4) Validasi De- 
sain, (5) Revisi Disain, (6) Ujicoba Produk, (7) Revisi Produk, (8) Ujicoba pemakaian, (9) Revisi Produk, dan (10) Produk Efektif \& layak. ${ }^{12}$

\section{Perencanaan dan Penyusunan Model Materi Ajar}

Borg dan Gall menyarankan untuk membatasi penelitian dalam skala kecil, termasuk dimungkinkannya untuk membatasi langkah-langkah penelitian. Oleh karena itu, dalam penelitian ini hanya sampai pada langkah mendapat produk akhir berupa pengembangan model materi ajar semantik berdasarkan acuan teoretik materi ajar yang ada sekarang dan identifikasi kebutuhan pengajar (dosen) dan pemelajar (mahasiswa). Dengan demikian, langkah-langkah pengembangan model materi ajar semantik ini dibagi menjadi tiga langkah, tanpa menghilangkan makna langkahan lainnya. Tiga langkah Borg dan Gall tersebut yakni: 1) Tahap persiapan penyusunan model, (2) Tahap pengembangan model, dan (3) Tahap evaluasi model. Agar lebih singkat menelaah rancangan pengembangan model materi ajar dapat dilihat pada roadmap berikut ini:

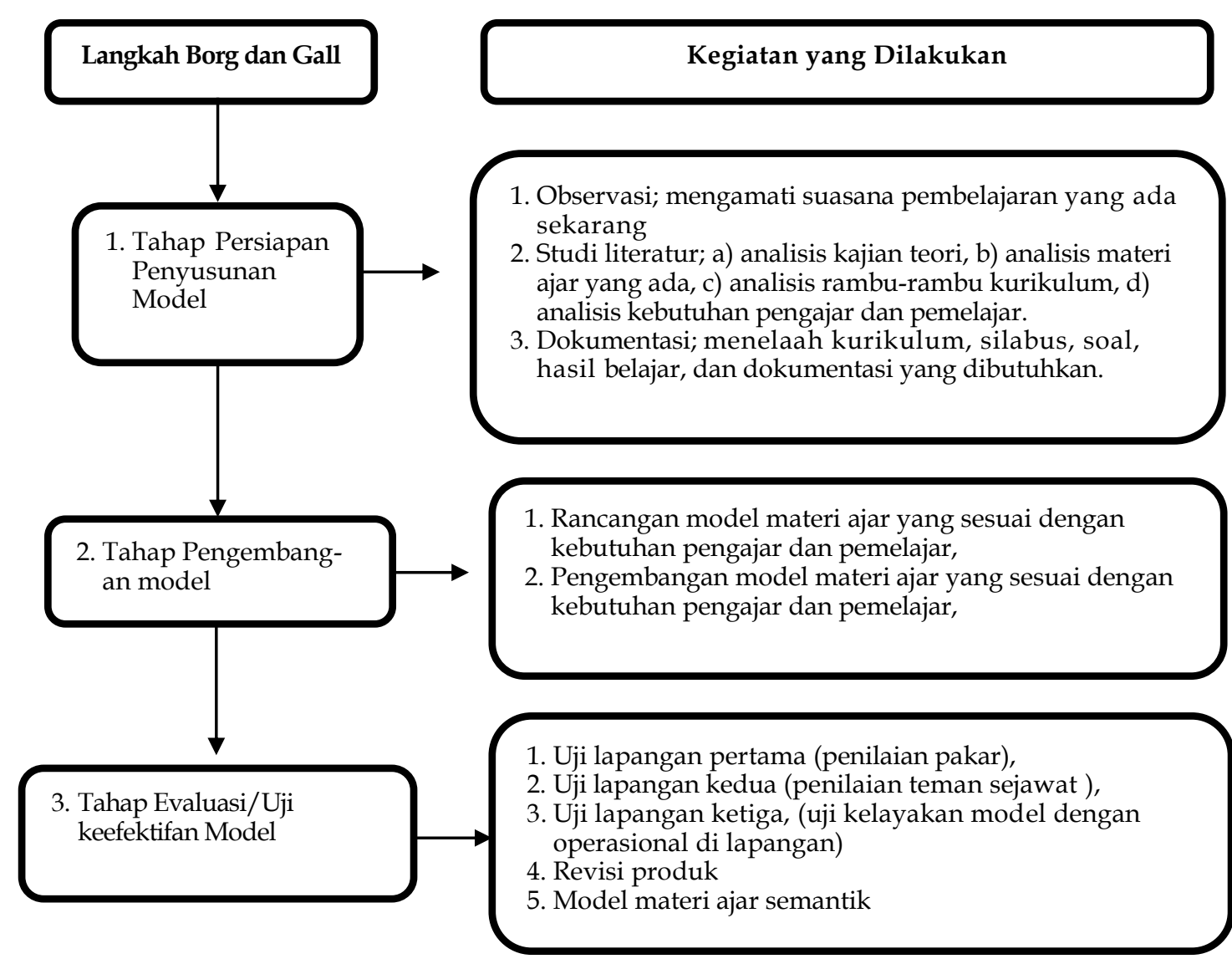

Gambar 1.

RancanganPengembangan Model Materi Ajar Menurut

Langkah Borg dan Gall 


\section{HASIL PENELITIAN DAN PEMBAHASAN}

\section{Hasil Pengembangan Model}

Pada hasil pengembangan model materi ajar ini digambarkan beberapa hal berikut (1) model teoritik, (2) gambaran tentang kebutuhan mahasiswa dan dosen pengajar terhadap materi ajar diperoleh melalui (a) hasil analisis kurikulum (b) hasil analisis silabus, dan (c) hasil analisis materi ajar semantik bahasa Indonesia, (3) gambaran rancangan silabus dan materi ajar semantik bahasa Indonesia.

\section{Model Teoretik}

Konsep teoritik pada penelitian ini merupakan konsepsi yang digunakan untuk merancang seperangkat materi ajar, dalam penelitian ini konsepsi materi ajar semantik bahasa Indonesia yang sesuai dengan kebutuhan mahasiswa dan dosen pengajar. Rancangan teoritik ini bersifat konseptual yang diperoleh dari kajian teori-teori yang dikemukakan para pakar pengembangan materi ajar dan pakar semantik bahasa. Ada beberapa prinsip dasar teori yang dijadikan acuan untuk mengembangkan materi ajar semantik bahasa Indonesia di Program Studi Pendidikan Bahasa, Sastra Indonesia,dan Daerah FKIP Universitas Jambi.

\section{Gambaran Kebutuhan Mahasiswa dan Dosen Pengajar}

\section{Gambaran Hasil Analisis Kurikulum}

Hasil analisis kurikulum Pertama, materi ajar semantik merupakan salah satu mata kuliah yang wajib diambil di Program Studi Pendidikan Bahasa, Sastra Indonesia, dan Daerah, diajarkan pada semester IV dengan bobot 2 dua SKS. Kedua, Tujuan mata kuliah semantik diajarkan agar mahasiswa mampu memahami materi ajar semantik yang ada hubungannya dengan kehidupan sehari-hari, baik secara lisan maupun tulisan. Ketiga, semantik termasuk ilmu bahasa. Ilmu bahasa terdiri atas empat tataran, yaitu fonologi, morfologi, sintaksis, dansemantik. Dari keempat cabang ilmu tersebut dapat dibagi menjadi dua bagian besar, yaitu tata bahasa (gramatika) atau struktur bahasa dan di luar gramatika atau di luar struktur bahasa. Semantik merupakan ilmu bahasa yang membahas tentang makna, baik makna kata, makna frasa, makna klausa, makna kalimat, maupun makna wacana sebagai satuan bahasa yang lengkap. Keempat, pengajaran semantik bahasa Indonesia adalah salah satu mata kuliah yang harus mahasiswa pelajari dalam kelompok mata kuliah kebahasaan. Pengajaran semantik yang harus dipelajari adalah (1) makna dalam Bahasa Indonesia yang mencakup: makna leksikal dan gramatikal, denotatif dan konotatif, lugas dan kias, dan makna dasar dan ubahan, (2) kerelasian makna yang mencakup: sinonim, antonim, polisemi, hiponimi, dan homonimi, (3) pengertian perubahan makna, sebab-sebab perubahan makna, dan arah perubahan, dan (4) pengertian ungkapan tabu, jenis-jenisnya, dan strategi penghindarannya. Kelima, mempunyai beberapa manfaat yang dapat mahasiswa peroleh dengan mempelajari dan menguasai mata kuliah Semantik Bahasa Indonesia ini, (a) secara langsung mahasiswa akan mempunyai pengetahuan tentang makna bahasa Indonesia. (b) penguasaan semantik akan meningkatkan ke- 
mampuan berbahasa mahasiswa. (c) penguasaan makna meningkatkan kemampuan pembelajaran bahasa mahasiswa, karena penguasaan makna ini berkaitan erat dengan sejumlah mata kuliah lain, yakni morfologi, sintaksis, pragmatik, membaca dan menulis.

\section{Gambaran Hasil Analisis Silabus}

Silabus yang dianalisis adalah silabus mata kuliah semantik yang digunakan dari tahun 2005 sampai dengan 2012 di Program Studi Pendidikan Bahasa, Sastra Indonesia, dan Daerah /S-1 FKIP Universitas Jambi.

Gambaran silabus yang sedang digunakan pada komponen tujuan tidak sesuai dengan kurikulum yang telah ditetapakan di Program Studi Pendidikan Bahasa, Sastra Indonesia, dan Daerah FKIP Universitas Jambi. Tujuan kurikulum Program Studi Pendidikan Bahasa, Sastra Indonesia, dan Daerah FKIP Universitas Jambi adalah agar mahasiswa mampu memahami semantik yang digunakan dalam kehidupan sehari-hari, baik secara lisan maupun tulisan. Oleh karena itu tujuan yang diharapkan dengan sajian mata kuliah pada perkuliahan tersebut adalah mahasiswa mampu memahami semantik. Komponen lainnya pada prinsipnya sudah sesuai. Oleh karenanya komponen tujuan perlu disesuaikan dengan kurikulum yang telah ditetapkan. Sesuai dengan perkembangan pendidikan komponen-komponen silabus selain harus disesuaikan dengan kurikulum juga harus dikembangkan sesuai dengan perkembangan pendidikan. Komponen-komponen yang dikembangkan sebagai berikut; identitas, deskripsi, kompetensi dasar, standar kompetensi, indikator, rincian materi ajar, dan materi pokok.

Hasil analisis silabus yang telah dikembangakan sebagai bagian dari analisis kebutuhan pengembangan materi ajar. Hasil analisis silabus diungkap dengan menggunakan enam belas item penilaian. Masing-masing penilai menyatakan komponenkomponen silabus penting dihadirkan dalam silabus. Seperti dilihat pada tabel berikut;

Dari 16 item pertanyaan sembilan item pernyataan menunjukkan penilaian penting $(\mathrm{P})$. Hal itu menunjukkan bahwa komponen-komponen tersebut penting $(\mathrm{P})$ di dalam pengembangan silabus. Komponen-komponen tersebut sebagai pedoman untuk pengembangan materi ajar dan pedoman untuk proses pembelajaran. Silabus merupakan bagian dari perencanaan pembelajaran dan dapat dijadikan pedoman untuk pengembangan materi ajar. Berdasarkan hasil wawancara dengan mahasiswa, bahwa selama ini dosen pengajar tidak pernah mengenalkan silabus semantik kepada mahasiswa. Padahal, mahasiswa sebagai calon pengajar, silabus perlu diperkenalkan kepada mereka agar mengetahui apa saja dan batas mana saja yang harus dipelajari.

\section{Gambaran Hasil Analisis Materi Ajar Semantik}

Hasil analisis materi ajar semantik ini diperoleh dengan dua cara yaitu Hasil analisis materi ajar semantik dengan (1) instrumen dan (2) wawancara. Hal ini digunakan untuk melihat gambaran kesesuaian pengembangan materi ajar dengan kriteria pengembangan materi ajar. 


\section{a. Hasil Analisis Materi Ajar Semantik dari Instrumen}

Hasil analisis materi ajar semantik melalui instrumen ini diperoleh dari tiga dosen pengajar untuk memperoleh gambaran model materi ajar yang dibutuhkan. Gambaran tersebut dapat dilihat pada hasil analisis materi ajar semantik dengan delapan belas item pertanyan menunjukkan penting $(\mathrm{P})$ materi ajar semantik dikembangkan, hanya item sembilan yang menunjukkan kurang penting (KP) yang tentunya akan diganti.

\section{b. Hasil Analisis Materi Ajar Semantik dari Wawancara}

Gambaran hasil analisis wawancara menunjukkan item 1 membuktikan bawa yang dijadikan responden penelitian adalah dosen pengajar semantik. Item 2 memastikan apakah dosen pengajar membuat materi ajar, ternyata satu dosen pengajar tidak membuat. Item 3 untuk mengetahui tujuan membuat materi ajar, tujuannya adalah membantu mahasiswa dalam memperoleh alternatif materi ajar di samping buku-bu$\mathrm{ku}$ teks yang terkadang sulit diperoleh. Memudahkan pengajar dalam melaksanakan pembelajaran. Item 4 untuk mengatahui tujuan yang ingin dicapai membuat materi ajar semantik, agar setiap kompetensi tercapai dan tuntas. Item 5 untuk mengetahui yang dijadikan sumber materi ajar semantik.Ternyata yang dapat dijadikan sumber materi ajar dapat berupa berupa bahan cetak, benda, alam, maupun orang ahli.Item 6 untuk mengetahui cakupan materi ajar semantik yang mereka buat.Ternyata pengakuannya cakupan materi ajar semantik yang mereka buat belum memenuhi kriteria materi ajar. Sehubungan dengan itu perlu dikembangkan. Item 7 untuk mengetahui apa yang dijadikan pedoman penulisan materi ajar, dari jawaban yang dikemukakan mereka pedoman penulisan materi ajar semantik adalah kurikulum dan silabus. Item 8 dan 9 untuk mengetahui membuat dan perlu membuat silabus mata kuliah semantik, jawan yang mereka kemukakan perlu. Item 10 untuk memastikan perlukah materi ajar dikembangkan oleh pengajar, mereka menjawab perlu. Item 11 untuk mengetahui manfaat menyusun materi ajar semantik bagi dosen pengajar dan mahasiswa. Manfaat yang diperoleh adalah sesuai tuntutan kurikulum, sesuai dengan kebutuhan belajar mahasiswa, mahasiswa tidak lagi tergantung kepada buku teks yang terkadang sulit untuk diperoleh, materi ajar menjadi labih kaya karena dikembangkan dengan menggunakan berbagai referensi, mahasiswa akan lebih banyak mendapatkan kesempatan untuk belajar secara mandiri dan mengurangi ketergantungan terhadap kehadiran pengajar. Item 12 untuk mengetahui idealnya materi ajar mulai dari yang mudah untuk memahami yang sulit, dari yang kongkret untuk memahami yang abstrak.

Berdasarkan data di atas dapat disimpulkan, manfaat menyusun materi ajar dapat memenuhi kebutuhan mahasiswa. Materi ajar yang mereka buat, menurut pernyataan dosen pengajar belum memehui kriteia (item 6).

\section{Gambaran Rancangan Model Silabus dan Materi Ajar yang Dikembangkan}

Berdasarkan hasil analisis kurikulum, silabus, materi ajar, dan analisis kebutuhan sebagai dasar untuk pengembanganmateri ajar. Gambaran rancangan pengem- 
bangannya dapat dilihat pada BAB IV Taber 4.5 merupakan gambaran hasil pengembangan silabus, sesuai dengan kebutuhan mahasiswa dan dosen pengajar. Silabus inilah akan menjadi dasar untuk pengembangan materi ajar semantik bahasa Indonesia.

\section{Gambaran Materi Ajar Semantik Bahasa Indonesia yang Telah Dikembangakan}

Pengembangan materi ajar semantik bahasa Indonesia ini, merupakan hasil analisis kebutuhan yang dikembangkan dari kurikulum kepada silabus, kemudian dikembangkan menjadi materi ajar.

Peta pengembangan model materi ajar ini adalah sebagai berikut;

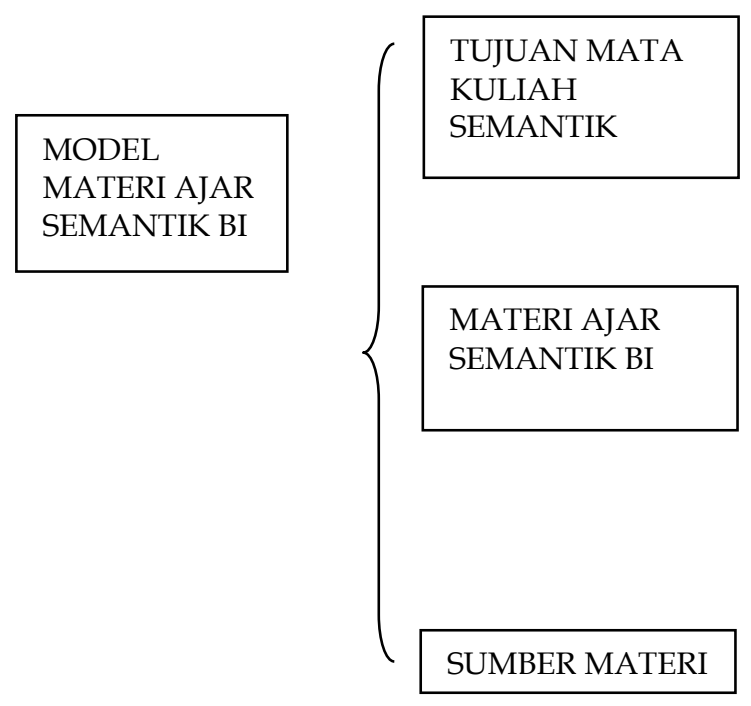

\begin{tabular}{|ll|}
\hline Materi Ajar I \\
1. & Standar Kompetensi \\
2. & Indikator \\
3. & Uraian Materi \\
4. & Rangkumam \\
5. & Latihan/Tugas \\
\hline Materi Ajar II \\
1. & Standar Kompetensi \\
2. & Indikator \\
3. & Uraian Materi \\
4. & Rangkumam \\
5. & Latihan/Tugas \\
\hline Materi Ajar III \\
1. & Standar Kompetensi \\
2. & Indikator \\
3. & Uraian Materi \\
4. & Rangkumam \\
\hline Materi Ajar IV \\
1. & Standar Kompetensi \\
2. & Indikator \\
3. & Uraian Materi \\
4. & Rangkumam \\
\hline Materi Ajar V \\
1. & Standar Kompetensi \\
2. & Indikator \\
3. & Uraian Materi \\
4. & Rangkumam \\
5. & Latihan/Tugas \\
\hline
\end{tabular}

Materi ajar yang dikembangkan pada penelitian ini merupakan hasil dari tahapan pengembangan model materi ajar. Hasil analisis model materi ajar yang utuh dapat dilihat pada lampiran.

\section{Kelayakan Model}

Penelitian pada tahap ini adalah tahap evaluasi kelayakan. Tahap evaluasi ini membahas tentang: (1) hasil penilaian pakar (Riview) terhadap materi ajar yang dikembangakan, (2) revisi materi ajar semantik berdasarkan hasil penilaian dan komentar pakar, (3) hasil uji coba terbatas (4) revisi materi ajar semantik berdasarkan hasil uji coba terbatas, (5) Hasil uji coba keterbacaan materi ajar semantik yang digunakan, (6) hasil pengujian lewat eksperimen, dan (7) revisi akhir materi ajar semantik. 


\section{Hasil Penilaian (Riview) Pakar}

Berdasarkan hasil penilaian para pakar, rata-rata hasil uji kelayakan para pakar menunjukkan materi ajar semantik memperoleh nilai rata-rata sebesar 3.76 atau dg kategori layak. Dengan demikian, secara teoretis dan konseptual berdasarkan penilaian para pakar, materi ajar semantik layak digunakan bagi mahasiswa Program Studi Pendidikan Bahasa, Sastra Indonesia, dan Daerah FKIP Universitas Jambi.

Dalam penilaian kualitatif, para pakar memberikan komentar, saran, dan rekomendasi terhadap materi semantik yang dinilainya. Komentar, saran, dan rekomendasi merupakan acuan, sumber data dan referensi untuk memperbaiki dan merevisi materi ajar semantik tersebut. Secara rinci, tabel berikut menggambarkan hasil koreksi, saran, komentar terhadap materi ajar semantik bahasa Indonesia.

\section{Hasil Uji Coba Terbatas}

\section{- Persepsi Mahasiswa terhadap Materi Ajar Semantik}

Setelah dilakukan revisi untuk penyempurnaan materi ajar semantik. Kemudian dilakukan ujicoba terbatas pada kelompok kecil. Ujicoba dilakukan dengan metode eksperimen. Mahasiswa yang menjadi sampel ujicoba sebanyak 10 orang. Uji coba digunakan untuk mengetahui kelayakan dan efektivitas materi ajar di lapangan.

Berdasarkan hasil uji coba terbatas dan penilaian mahasiswa pada materi ajar semantik diperoleh nilai rata-rata 3,96 dengan kategori baik. Dengan demikian materi ajar semantik layak digunakan sebagai pegangan oleh mahasiswa Program Studi Pendidikan Bahasa Sastra Indonesia, dan Daerah FKIP Universitas Jambi.

Penilaian, saran, komentar, dan rekomendasi mahasiswa merupakan acuan untuk memperbaiki materi ajar. Mahasiswa memberi andil dalam penilaian kualitatif terhadap materi ajar yang digunakannya.

\section{- Persepsi Dosen Pengajar terhadap Materi Ajar Semantik}

Pada uji coba terbatas, peneliti menyebarkan angket untuk mengetahui persepsi dosen pengajar, sebagai pengguna materi ajar yang diujicobakan. Hasil persepsi berupa penilaian dosen pengajar sangat penting untuk revisi materi ajar yang dikembangkan ini.

Dari angket persepsi dosen diperoleh data kualitatif dan kuantitatif. Data kualitatif berupa komentar, saran, dan rekomendasi. Berdasarkan hasil persepsi dosen pengajar secara kuantitatif, diperoleh nilai rata-rata akhir 4.02 dengan kategori baik. Dengan demikian, materi ajar semantik bahasa Indonesia layak dan relevan digunakan di Program Studi Pendidikan Bahasa, Satra Indonesia, dan Daerah FKIP Universitas Jambi.

Data kualitatif, diperoleh dari angket hasil persepsi dosen pengajar memberikan komentar, saran, dan rekomendasi terhadap materi ajar semantik bahasa Indonesia. Data tersebut merupakan acuan untuk revisi materi ajar semantik bahasa Indonesia.

\section{Hasil Uji Coba Keterbacaan Materi Ajar Semantik yang Digunakan}

Setelah melakukan uji coba terbatas dan revisi materi ajar semantik. Kemudian melakukan uji coba keterbacaan materi ajar yang digunakan sebagai model materi 
ajar semantik yang diberikan dalam proses pembelajaran. Uji coba keterbacaan dilakukan dengan cara mahasiswa memberikan penilaian terhadap materi ajar I, II, III, IV, dan V. Tingkat keterbacaan materi ajar semantik tergolong tinggi yaitu skor 3,91. Hal itu menunjukkan bahwa materi ajar semantik yang dikembangkan mudah dipahami.

\section{Hasil Pengujian Lewat Eksperimen}

Validasi materi ajar dilakukan di kelas A dan B dengan semester, Prodi, dan mata kuliah yang ditawarkan sama. Rancangan penelitian kelas A sebagai eksperimen dan kelas B sebagai kelompok kontrol. Dua kelompok akan dibandingkan dari hasil pretes dan posttes. Perbedaan kelompok eksperimen dan kelompok kontrol apakah ada perbedaan yang signifikan. Hasil perhitungan menunjukan apakah materi ajar yang dikembangkan ada perbedaan antara materi ajar sebelum dikembangkan dan sesudah dikembangkan. Hal tersebut dapat diketahui melalui pretest dan posttest pada kelompok eksperimen dan kontrol. Perbedaan kelompok ekperimen dan kelompok kontrol dapat diketahui melalui perhitungan uji t dan chi kuadrat pada tabel berikut:

Tabel 1.

Ringkasan Hasil Uji Perbedan

\begin{tabular}{|l|l|l|l|}
\hline No & Komponen & $\begin{array}{l}\text { Kelompok } \\
\text { Kontrol }\end{array}$ & $\begin{array}{l}\text { Kelompok } \\
\text { Eksperimen }\end{array}$ \\
\hline 1 & Rata-rata pretes & 52.281 & 51.313 \\
\hline 2 & Rata-rata posttes & 55.938 & 80.219 \\
\hline 3 & Jumlah responden & 32 & 32 \\
\hline 4 & $\mathrm{t}_{\text {hitung }}$ & 6.14 & 24.34 \\
\hline 5 & $\mathrm{t}_{\text {tabel }}$ & 1.99 & 1.99 \\
\hline
\end{tabular}

Berdasarkan tabel di atas menunjukkan perbedaan yang signifikan antara kelompok eksperimen dan kontrol. Kelompok kontrol rata-rata pretesnya 52.281, kelompok eksperimen rata-rata pretesnya 51.313. Kelompok kontrol rata-rata posttesnya 55.938, kelompok eksperimen rata-rata posttesnya 80.219. Kelompok ekperimen menunjukkan perbedaan yang sangat tinggi setelah dilakukan posttest bila dibandingkan dengan kelompok kontrol.

Melalui perhitungan uji $\mathrm{t}$, kelas eksperimen menunjukkan perbedaan yang signifikan yaitu $t_{\text {hitung }}>t_{\text {tabel }}$, $t_{\text {hitung }}=24.34, t_{\text {tabel }}=1.99$ sehingga Ho: ditolak Ha: diterima . Dengan demikian terdapat perbedaan yang signifikan sebelum dan sesudah pengembangan materi ajar. Hal itu menunjukkan bahwa pengembangan materi ajar telah berhasil, materi yang dikembangkan mudah dipahami oleh mahasiswa.

Melalui perhitungan uji $\mathrm{t}$, kelas kontrol menunjukkan perbedaan yang sinifikan yaitu $t_{\text {hitung }}>t_{\text {tabel, }}, t_{\text {hitung }}=6.14, t_{\text {tabel }}=1.99$ sehingga Ho: ditolak Ha: diterima. Dengan demikian terdapat perbedaan yang sinifikan sebelum dan sesudah pengembangan materi ajar, namun tidak menunjukkan perbedaan yang berarti seperti kelas eksperimen (perlakuan).

Dengan perhitungan chi kuadrat dua sampel untuk mengetahui tingkat perbedaan pengaruh perlakuan dengan yang bukan perlakuan, apakah ada atau tidak ada 
pengaruh setelah dilakukan pengembangan. Demikian juga untuk mengetahui apakah ada pengaruh positif pengembangan materi ajar semantik. Tingkat pengaruh perlakuan dapat diperoleh dengan perhitungan chi kuadrat.

Tabel 2.

Hasil Perhitungan Perbedaan pengaruh Perlakuan dan tidak Perlakuan

\begin{tabular}{|l|l|l|l|}
\hline \multirow{2}{*}{ Kelompok } & \multicolumn{2}{|l|}{ Tingkat Pengaruh Perlakuan } & \multirow{2}{*}{ Jumlah } \\
\cline { 2 - 4 } & Berpengaruh & Tak Berpengaruh & \\
\hline Eksperimen & 32 & 0 & 32 \\
\hline Kontrol & 21 & 11 & 32 \\
\hline & 53 & 11 & 64 \\
\hline
\end{tabular}

$\chi^{2}=\frac{n(|a d-b c|-0,5 n)^{2}}{(a+b)(a+c)(b+d)(c+d)}$

$\chi_{\text {hitung }}^{2}=10.98$

$\chi^{2}{ }_{\text {tabel }}=3.841$

$\left.\chi_{\text {hitung }} \chi^{\mathbf{2}}{ }_{\text {tabel }} \chi^{\mathbf{2}}{ }_{\text {hitung }}=10.98 \chi_{\text {tabel }}=3.841\right)$, sehingga Ho: ditolak Ha: diterima. Dengan demikian terdapat perbedaan yang sinifikan sebelum dan sesudah pengembangan materi ajar, namun tidak menunjukekan perbedaan yang berarti pada kelompok kontrol. Setelah dilakukan pengembangan materi ajar semantik mahasiswa lebih mudah memahami.

\section{SIMPULAN, IMPLIKASI, DAN REKOMENDASI}

\section{Simpulan}

Hasil uji coba terbatas setelah dilakukan revisi untuk penyempurnaan materi ajar semantik. Kemudian dilakukan uji coba terbatas pada kelompok kecil. Uji coba dilakukan dengan metode eksperimen. Mahasiswa yang menjadi sampel uji coba terbatas sebanyak 10 orang. Uji coba digunakan untuk mengetahui kelayakan dan efektivitas materi ajar di lapangan. Berdasarkan hasil uji coba terbatas dan penilaian mahasiswa pada materi ajar semantik diperoleh nilai dengan kategori baik. Dengan demikian, materi ajar semantik layak digunakan sebagai pegangan mahasiswa Program Studi Pendidikan Bahasa Sastra Indonesia dan Daerah FKIP Universitas Jambi. Persepsi dosen pengajar mata kuliah semantik pada uji coba terbatas, peneliti menyebarkan angket untuk mengetahui persepsi dosen pengajar. Persepsi dosen diperoleh data kualitatif dan kuantitatif. Data kualitatif berupa komentar, saran, dan rekomendasi. Sedangkan data kuantitatif dengan memberikan penilai akhir 4.02 dengan kategori baik. Dengan demikian, materi ajar semantik bahasa Indonesia layak dan relevan digunakan di Program Studi Pendidikan Bahasa, Satra Indonesia, dan Daerah FKIP Universitas Jambi.

Hasil uji coba keterbacaan materi ajar semantik dilakukan dengan cara mahasiswa memberikan penilaian terhadap materi ajar I, II, III, IV, dan V. Tingkat keterbacaan materi ajar semantik tergolong tinggi. Hal itu menunjukkan bahwa materi ajar semantik yang dikembangkan mudah dipahami. 
Hasil pengujian lewat eksperimen yaitu melakukan uji validitas dan efektivitas. Validasi materi ajar dilakukan di kelas A dan B dengan semester, Prodi, dan mata kuliah yang ditawarkan sama. Hasil perhitungan perbedaan kelompok ekperimen dan kelompok kontrol menunjukkan perbedaan yang signifikan antara kelompok eksperimen dan kontrol. Kelompok kontrol rata-rata pretesnya 52.281, kelompok eksperimen rata-rata pretesnya 51.313. Kelompok kontrol rata-rata posttestnya 55.938, kelompok eksperimen rata-rata posttesnya 80.219. Hasil perhitungan uji t menunjukkan terdapat perbedaan yang signifikan antara kelompok kontrol dan eksperimen. Kelompok kontrol t hitungnya 6,14, sedangkan kelompok eksperimen t hitungnya 24, $\mathrm{t}$ table 1,99. Berdasarkan hasil perhitungan chi kuadrat $\square{ }^{2}$ hitung $=10.98, \square{ }^{2}$ tabel $=3.841$. $\square 2_{\text {hitung }}>\square$ tabel. Dapat disimpulkan setelah dilakukan pengembangan mahasiswa lebih mudah memahami materi ajar.

\section{Implikasi}

Berdasarkan kesimpulan di atas, terdapat beberapa implikasi. Pertama, perlu pengembangan materi ajar oleh pengajar, Karena, (1) Materi ajar adalah seperangakat materi yang disusun secara sistematis baik tertulis atau pun tidak sehingga tercipta lingkungan atau suasana yang memungkinkan siswa untuk belajar. (2) Pengembangan materi ajar adalah apa yang dilakukan dosen pengajar, guru, atau peserta didik untuk memberikan sumber masukan berbagai pengalaman yang dirancang untuk meningkatkan belajar bahasa. (3) Prinsip pengembangannya; dapat memberi dampak, memberi perasaan mudah bagi pembelajar, mengembangkan rasa percaya diri pembelajar, relevan dan berguna bagi pembelajar, mengarahkan dan memfasilitasi pembelajar untuk menemukan sendiri, membuat pembelajar siap belajar dengan topik-topik yang sedang diajarkan, memperhatikan perbedaan gaya belajar, memperhatikan pengaruh positif terhadap pelajaran, memperhatikan sikap pembelajar, menyediakan kesempatan umpan balik kepada pembelajar. (4) Pengembangan materi ajar meliputi; identifikasi kebutuhan pengajar dan pembelajar, penentuan kegiatan eksplorasi kebutuhan materi, realisasi kontekstual dengan mengajukan gagasan yang sesuai, pemilihan teks, dan konteks materi ajar, realisasi pedagogis melalui tugas dan latihan dalam materi ajar, produksi materi ajar, penggunaan materi ajar oleh pembelajar, dan evaluasi materi ajar.

Kedua, penting melakukan penngembangan kurikulum, silabus, materi ajar, dan evaluasi. Hal tersebut merupakan bagian dari perencanaan pembelajaran. Manfaat menyusun materi ajar bagi dosen pengajar dan mahasiswa adalah sesuai tuntutan kurikulum dan sesuai dengan kebutuhan belajar mahasiswa. Mahasiswa tidak lagi tergantung kepada buku teks yang terkadang sulit untuk diperoleh. Materi ajar menjadi lebih kaya karena dikembangkan dengan menggunakan berbagai referensi. Mahasiswa akan lebih banyak mendapatkan kesempatan untuk belajar secara mandiri dan mengurangi ketergantungan terhadap kehadiran pengajar. Idealnya materi ajar mulai dari yang mudah untuk memahami yang sulit, dari yang kongkret untuk memahami yang abstrak. 


\section{Rekomendasi}

Berdasarkan kesimpulan dan implikasi yang telah dikemukakan, pengembangan materi ajar semantik terdapat beberapa rekomendasi. Pertama, bagi pengajar perlu melakukan pengembangan materi ajar agar pembelajar mendapat sumber masukan berbagai pengalaman yang dirancang untuk meningkatkann hasil belajar, dapat memberi dampak, memberi perasaan mudah bagi pembelajar, mengembangkan rasa percaya diri pembelajar, relevan dan berguna bagi pembelajar, mengarahkan dan memfasilitasi pembelajar untuk menemukan sendiri, membuat pembelajar siap belajar dengan topik-topik yang sedang diajarkan, memperhatikan perbedaan gaya belajar, memperhatikan pengaruh positif terhadap pelajaran, memperhatikan sikap pembelajar, menyediakan kesempatan umpan balik kepada pembelajar.

Kedua, hasil pengembangan materi ajar dapat digunakan oleh pengajar dan pembelajar dalam pembelajaran sebagai; penyajian materi ajar, sumber kegiatan bagi peserta didik untuk berlatih komunikasi secara interaktif, rujukan informasi kebahasaan, sumber stimulan dan gagasan suatu kegiatan kelas, dan bantuan bagi guru yang kurang berpengalaman untuk menumbuhkan kepercayaan diri.

Ketiga, Sebaiknya dosen pengajar memberikan pemahaman dengan baik mengenai materi ajar semantik, karena mahasiswa akan menjadi guru di sekolah menengah pertama dan menengah atas.

Keempat, dosen pengajar dan mahasiswa Prodi Pendidikan Bahasa, Sastra Indonesia, dan Daerah dapat menjadikan hasil pengembangan materi ajar sebagai acuan atau rujukan untuk mengajar dan penelitian penngembangan materi ajar berikutnya.

\section{CATATAN AKHIR:}

1. S. Nasution, Teknologi pendidikan, Jakarta: Penerbit Bumi Aksara, 1982.

2. Haryadi, Hubungan intensitas mendengarkan ceramah, pemahaman buku teks dan partisipasi berorganisasi dengan retorik, Jurnal Kependidikan Nomor 2 Tahun XXXIII, Yogyakarta: Lembaga Penelitian Universitas Negeri Yogyakarta, 2003.

3. Ch. F. Hockett, A Course in Modern Linguistics, New York: The Macmillan and Co, 1958, h. 33.

4. Geoffrey Leech, Semantik (Terjemahan: Paina Partana), Yogyakarta: Pustaka Pelajar, 2003, h. 7- 9.

5. John Lyons, Pengantar teori Linguistik (Introduction to Theoritical Linguistics), (terjemah), Jakarta: Gramedia Pustaka Utama, 1995, h. 396.

6. Suyudi, Relasi Makna, 2009. http:/ / www.studycycle.net/2009/11/relasi-makna.html

7. Haryadi, op.cit.

8. Stephen Ullmann, Smantics, An Introduction to the Science of Meaning, Basil Blachwell, Oxford, 1977, h. 156.

9. Tim Dosen, Kurikulum dan Deskripsi Mata Kuliah, Prodi Bahasa Indonesia Jurusan PBS FKIP Unja, Jambi: FKIP Unja, 2005, h. 7.

10. Meredith D. Gall, Joyce Gall, dan Walter R. Borg, Educational Research: An Introduction, Boston: Pearson: Education, Inc., 2003.

11. R. C. Richey dan J. D. Klein, Design and Development Research Methods, Strategies, and Issues, London: Lawrence Erlbaum Associates, Inc., 2007.

12. Conny R. Semiawan, Catatan Kecil tentang Penelitian dan Pengembangan Ilmu Pengetahuan, Jakarta: Kencana, 2007, h. 184. 


\section{DAFTAR PUSTAKA}

Gall, Meredith D., Joyce Gall, dan Walter R. Borg. Educational Research: An Introduction. Boston: Pearson: Education, Inc., 2003.

Haryadi. "Hubungan Intensitas Mendengarkan Ceramah, Pemahaman Buku Teks dan Partisipasi Berorganisasi dengan Retorik." Jurnal Kependidikan. Nomor 2 Tahun XXXIII. Yogyakarta: Lembaga Penelitian Universitas Negeri Yogyakarta, 2003.

Hockett, Ch. F. A Course in Modern Linguistics. New York: The Macmillan and Co., 1958.

Leech, Geoffrey. Semantik (Terjemahan: Paina Partana). Yogyakarta: Pustaka Pelajar, 2003.

Lyons, John. Senatics. New York: Cambridge University Press, 1984.

Lyons, John. Pengantar Teori Linguistik (Introduction to Theoritical Linguistics). (terjemah). Jakarta: Gramedia Pustaka Utama, 1995.

Nasution, S. Teknologi pendidikan. Jakarta: Penerbit Bumi Aksara, 1982.

Richey, R. C. dan J. D. Klein. Design and Development Research Methods, Strategies, and Issues. London: Lawrence Erlbaum Associates, Inc., 2007.

Semiawan, Conny R. Catatan Kecil tentang Penelitian dan Pengembangan Ilmu Pengetahuan. Jakarta: Kencana, 2007.

Suyudi, Relasi Makna, 2009. http://www.studycycle.net/2009/11/relasi-makna.html.

Tim Dosen. Kurikulum dan Deskripsi Mata Kuliah. Prodi Bahasa Indonesia Jurusan PBS FKIP Unja, Jambi: FKIP Unja, 2005.

Ullmann, Stephen. Semantics, An Introduction to the Science of Meaning. Basil Blachwell, Oxford. 1977. 